Eur. J. Clin. Chem. Clin. Biochem.

Vol. 29, 1991, pp. 657-664

(C) 1991 Walter de Gruyter \& Co. Berlin. New York

\title{
Dual Effect of Lovastatin and Simvastatin on LDL-Macrophage Interaction
}

\author{
By $M$. Aviram, S. Keidar and G. J. Brook \\ Lipid Research Unit, Rambam Medical Center and Rappaport Institute for Research in the Medical Sciences, \\ Technicon Faculty of Medicine, Haifa, Israel
}

(Received February 25/June 10,1991)

Summary: Lovastatin and simvastatin which are very potent cellular cholesterol biosynthesis inhibitors, significantly affect the plasma lipoprotein concentration.

After incubation of plasma with ${ }^{14} \mathrm{C}$-labelled compounds, radioactivity was found in all lipoprotein fractions but mainly $(40 \%)$ in high density lipoprotein (HDL), and in the lipoprotein-deficient plasma fraction $(20-30 \%)$. Drug-treated lipoproteins showed reduced electrophoretic mobility on cellulose acetate in comparison with control lipoproteins. The lovastatin-treated low density lipoprotein (LDL) displayed $28 \%$ increased fluidity in comparison with control LDL. The immunoreactivity of drug-treated LDL with monoclonal antibody directed towards the LDL receptor binding domains (B1B6) was significantly less than that of control LDL, suggesting reduced binding to the LDL receptor. When drug-treated LDL was incubated with J-774 A.1 macrophage-like cell line, its binding (at $4^{\circ} \mathrm{C}$ ) was $28 \%$ less than that of control LDL, whereas a substantial increase in the cellular cholesterol esterification rate (by $83 \%$ with lovastatin and by $67 \%$ with simvastatin) was noted. Similarly, the degradation of lovastatin and simvastatin-treated LDL by macrophages was $87-89 \%$ greater than that of control LDL. The "apparent $\mathrm{V}_{\max }$ " for the macrophage degradation of lovastatin-treated LDL was $70 \%$ greater than that for control LDL. Thus, both drugs may have a dual effect on the macrophage uptake of LDL; they may increase the number of LDL receptors on the cell surface, but they may also reduce the affinity of LDL for its receptor, the former being the major effect. If the in vitro changes caused by drug-treated LDL also occur in vivo, then the cellular uptake of LDL and plasma cholesterol concentration could be determined by the magnitude of each of the opposing effects of the drugs.

\section{Introduction}

Lovastatin, a potent hypocholesterolaemic drug has a profound effect on plasma lipoprotein composition and concentration $(1-4)$. Lovastatin inhibits cellular cholesterol biosynthesis and increases the number of low density lipoprotein (LDL) receptors on the surface of cells (5). Plasma concentration of LDL is determined by the LDL receptor activity which is the result of the number of the receptors as well as the affinity of the lipoproteins for these receptors. The present study was undertaken to find out whether lovastatin as well as simvastatin bind to plasma lipoproteins and whether such interaction affects the physico-chemical properties of the lipoproteins and their interaction with cells.

\section{Methods}

Experimental procedure

Whole plasma was incubated for $1 \mathrm{~h}$ at $37^{\circ} \mathrm{C}$ with $0.1-100$ $\mu \mathrm{mol} / 1$ of unlabelled lovastatin or simvastatin, or with $20 \mathrm{GBq} / \mathrm{l}$ [butanoate $-1-{ }^{14} \mathrm{C}$ ] Mevacor (lovastatin) with specific radioactivity of $1.4 \mathrm{MBq} / \mathrm{mg}$ or with [butanoate $-1-{ }^{14} \mathrm{C}$ ] Zocor (simvastatin) with a similar concentration and with a similar specific radioactivity. Lipoproteins were then separated by discontinuous density gradient ultracentrifugation (6). Lipoproteins were also treated directly in some experiments with $100 \mu \mathrm{mol} / 1$ of unlabelled or labelled drugs for $1 \mathrm{~h}$ at $37^{\circ} \mathrm{C}$ prior to separation by ultracentrifugation. Lovastatin was solubilized in dimethyl sulphoxide (DMSO), whereas simvastatin was solubilized in ethanol. Control LDL preparations incubated under similar conditions with the appropriate solvents were always used for comparison with the drug-treated LDL. We chose a wide range of drug concentrations, because the plasma levels of the drugs during clinical dosage range from $0: 1$ to $1.0 \mu \mathrm{mol} / 1(7,8)$. The plasma concentration of the drug is affected by its absorption 
ratc, its time in the intestine as well as by its rapid passage through the liver, its high metabolic rate and its short plasma half life. The drugs were a generous gift from Merck Sharp and Dohme Research Laboratories (Rahway N. J., U.S. A.).

\section{Lipoproteins}

Lipoprotein electrophoresis was carried out on cellulose acetate (9), on sodium dodecyl sulphate (SDS) polyacrylamide gels (10) and on non-denatured gradient gels (11). Protein in the lipoproteins and the cells was determined by the Lowry method (12). Lipoprotein cholesterol was measured with the enzymatic kit (Sigma Co., St. Louis, MO) and phospholipids, by the method of Bartlett (13). Lipoprotein oxidation was measured by the thiobarbituric acid reactive substances assay (14).

Solid phase competitive binding radioimmunoassay

LDL, drug-associated LDLs and LDL incubated with the appropriate solvents (control LDLs) were assayed in competitive displacement assays on microtitre plates (15). The plates were coated with $140 \mu \mathrm{l}$ of $10 \mathrm{mg} / \mathrm{l}$ purified monoclonal antibody B1B6 (this antibody is directed towards the LDL receptor binding domains on apolipoprotein B-100 and mapped to amino acid residues $3114-3606$; it was a generous gift from Drs. G. Schonfeld and E. Krul, Washington Univ., St. Louis, MO, U.S.A.). Wells were blocked with $30 \mathrm{~g} / 1$ bovine serum albumin - phosphate buffered saline. Serial dilutions of the lipoproteins were added followed by the addition of a constant amount of $\left[{ }^{125} \mathrm{r}\right] \mathrm{LDL}(500 \mathrm{ng})$. After incubation for $4 \mathrm{~h}$ at room temperature, the wells were washed 3 times with phosphatebuffered saline, and binding (B) was determined. The maximum binding $\left(B_{0}\right)$ was determined in wells where competing lipoprotein was not added. The results are expressed as the $\mathrm{B} / \mathrm{B}_{\circ}$ ratio and each point is the mean of two measurements (CV $<10 \%)$.

\section{Lipoprotein fluidity}

The steady-state fluorescence polarization of diphenylhexatriene incorporated into lipoproteins was measured (16). The analysis was carried out with a spectrofluorimeter equipped with polarizers. Lipoproteins (protein $=50 \mathrm{mg} / \mathrm{l}$ ) were incubated with $100 \mu \mathrm{mol} / \mathrm{l}$ diphenylhexatriene for 30 minutes at $37^{\circ} \mathrm{C}$. Fluorescence polarization measurements were carried out at various temperatures and the anisotropy was determined. The anisotropy parameter is inversely related to the fluidity and is given as $\left[\left(\mathrm{r}_{0} / r-1\right)\right]$ where $r$ is the fluorescent anisotropy obtained from the polarization analysis and $r_{0}$ is the upper theoretical limit of the anisotropy.

\section{Cells}

Monolayer cultures of J-774A.1 murine macrophage-like cells were grown and maintained in Dulbecco Modified Eagles Medium (DMEM) supplemented with a 0.1 volume fraction of fetal bovine serum, penicillin $\left(100 \cdot 10^{3} \mathrm{U} / \mathrm{l}\right)$, streptomycin $(100$ $\mathrm{mg} / \mathrm{l})$ and glutamine $(2 \mathrm{mmol} / \mathrm{l})$. The cells were fed twice every week. Human skin fibroblasts were cultured form punch biopsies of the skin of the anterior thigh from normal volunteers. Subcultures were used between passages $4-12$. The cells were plated at $5 \times 10^{5}$ cells $/ 35-\mathrm{mm}$ dishes in DMEM supplemented with a 0.1 volume fraction of fetal calf serum, $100 \cdot 10^{3} \mathrm{U} / 1$ penicillin, $100 \mathrm{mg} / \mathrm{l}$ streptomycin, and $2 \mathrm{mmol} / \mathrm{l}$ glutamine. After five days in culture, the medium was changed to DMEM supplemented with a 0.1 volume fraction of human lipoproteindeficient serum (d $>1.25 \mathrm{~kg} / \mathrm{l}$, prepared by ultracentrifugation). for $48 \mathrm{~h}$ to upregulate cellular LDL receptors.

\section{Macrophage cholesterol esterification}

Lipoproteins (protein $=25 \mathrm{mg} / \mathrm{l}$ ) were incubated with the cells for 5 hours at $37^{\circ} \mathrm{C}$ in the presence of $370 \mathrm{MBq} / 1$ of ${ }^{3}[\mathrm{H}]$ oleic acid $(0.27 \mathrm{nmol} / \mathrm{l}, 83 \mathrm{nmol}$ oleate per $\mathrm{mg}$ albumin). At the end of the incubation, cellular lipids were extracted with hexaneisopropanol $(3+2$, by vol.) and the cholesteryl ester was separated by thin layer chromatography (hexane : ether : acetic acid, $130+30+1.5$, by vol.), scraped into vials containing 15 $\mathrm{ml}$ scintillation fluid and counted in a beta scintillation counter (17).

Lipoprotein binding to macrophages and fibroblasts

High affinity binding of ${ }^{125}$ I-labelled lipoproteins to cells was studied in the absence or presence of 50 fold excess of unlabelled lipoproteins after $4 \mathrm{~h}$ of incubation at $4{ }^{\circ} \mathrm{C}$. Cells were washed (x4) with phosphate-buffered saline, extracted with $0.1 \mathrm{~mol} / 1$ $\mathrm{NaOH}(1 \mathrm{~h}$ at room temperature) and the bound radiolabelled LDL was counted in a scintilation counter.

Lipoprotein degradation by macrophages and fibroblasts

Lipoprotein degradation by cells was measured following incubation of [ $\left.{ }^{125} \mathrm{I}\right] \mathrm{LDL}$, lovastatin-associated [ $\left.{ }^{125} \mathrm{I}\right] \mathrm{LDL}$, and simvastatin=associated $\left.{ }^{125} \mathrm{I}\right] \mathrm{LDL}$ with cells for $5 \mathrm{~h}$ at $37^{\circ} \mathrm{C}$. The hydrolysis of LDL protein was assayed in the incubation medium by measurement of trichloroacetic acid-soluble, non iodide radioactivity (17). Cell-free LDL degradation was minimal and was subtracted from total LDL degradation. The cell layer was washed three times with phosphate-buffered saline and extracted by a $1 \mathrm{~h}$ incubation at room temperature with $0.5 \mathrm{ml}$ of $0.1 \mathrm{~mol} / 1 \mathrm{NaOH}$ for measurement of protein.

\section{Statistics}

Results are given as mean \pm S.D. Significance was analysed by the Wilcoxon rank test.

\section{Results}

The partition of lovastatin and simvastatin among the various plasma lipoproteins was studied by incubating whole plasma from normolipidaemic subjects for $1 \mathrm{~h}$ with $10 \mu \mathrm{mol} / \mathrm{l}$ of ${ }^{14} \mathrm{C}$-labelled lovastatin or simvastatin, followed by lipoprotein separation (using discontinuous density gradient ultracentrifugation). Table 1 demonstrates that the largest fraction of radioactivity $(38 \%)$ was associated with high density lipoproteins (HDL). The drugs were also associated with very low density lipoprotein (VLDL) and low density lipoprotein (LDL), while $20-30 \%$ of the radioactivity was recovered in the lipoprotein-deficient plasma fraction. When expressed per mg of protein, the drug binding capacity was similar for all lipoproteins (tab. 1).

The binding capacity of simvastatin for HDL, LDL and VLDL was, however, 3, 4 and 6 times greater, respectively, than that of lovastatin (tab. 1). The addition of 10 fold excess unlabelled lovastatin or sim- 
Tab. 1. Distribution of lovastatin and simvastatin among plasma lipoproteins.

\begin{tabular}{|c|c|c|c|c|}
\hline & \multicolumn{2}{|c|}{ Lovastatin } & \multicolumn{2}{|c|}{ Simvastatin } \\
\hline & $\begin{array}{l}\mathrm{ng} / \mathrm{mg} \\
\text { protein }\end{array}$ & $\%$ & $\begin{array}{l}\mathrm{ng} / \mathrm{mg} \\
\text { protein }\end{array}$ & $\%$ \\
\hline $\begin{array}{l}\text { VLDL } \\
\text { LDL } \\
\text { HDL } \\
\text { LPDP }\end{array}$ & $\begin{array}{r}244 \\
303 \\
319 \\
16\end{array}$ & $\begin{array}{l}12 \\
20 \\
38 \\
30\end{array}$ & $\begin{array}{r}1400 \\
1236 \\
824 \\
11\end{array}$ & $\begin{array}{l}15 \\
25 \\
40 \\
20\end{array}$ \\
\hline
\end{tabular}

Whole plasma was incubated with $20 \mathrm{MBq} / 1$ of ${ }^{14} \mathrm{C}$-labelled lovastatin or simvastatin $(100 \mu \mathrm{mol} / \mathrm{l})$ for $1 \mathrm{~h}$ at $37^{\circ} \mathrm{C}$, followed by lipoprotein separation using discontinuous density gradient ultracentrifugation. Radioactivity was determined in each fraction and expressed as percent of total radioactivity (\%) or as $\mathrm{ng}$ of drug associated with $1 \mathrm{mg}$ of lipoprotein protein. Results are the means of triplicates; they are representative of the results of 3 experiments which varied by less than $10 \%$. VLDL - very low density lipoprotein. LDL - low density lipoprotein. HDL - high density lipoprotein. LPDP - lipoprotein deficient plasma.

Tab. 2. Distribution of lovastatin among plasma lipoproteins: drug concentration study.

\begin{tabular}{|c|c|c|c|c|}
\hline \multirow{2}{*}{$\begin{array}{l}\text { Lovastatin } \\
\text { concentration } \\
(\mu \mathrm{mol} / \mathrm{l})\end{array}$} & \multicolumn{4}{|c|}{$\%$ of total radioactivity } \\
\hline & $\overline{\text { VLDL }}$ & LDL & $\mathrm{HDL}$ & LPDP \\
\hline 0.01 & 10 & 15 & 30 & 45 \\
\hline 0.1 & 6 & 18 & 35 & 41 \\
\hline 1.0 & 6 & 18 & 38 & 38 \\
\hline 10 & 15 & 20 & 33 & 32 \\
\hline
\end{tabular}

The study was carried out under similar conditions to those described in table 1.

vastatin to the plasma for the period of incubation with the labelled druig resulted in $45 \%$ and $31 \%$ reduction in LDL-associated drug respectively, suggesting specific drug binding to the lipoproteins. To study the effect of lovastatin at concentrations below those present in plasma during clinical dosage, plasma was incubated for 1 hour with labelled lovastatin at concentrations of $0.1,1.0$ and $10 \mu \mathrm{mol} / 1$, and the distribution of the radioactivity was determined (tab. 2). The results revealed a similar pattern to that shown with $100 \mu \mathrm{mol} / 1$ of lovastatin (tab. 1). The levels of LDL cholesterol, phospholipids and protein were unchanged after lipoprotein incubation with the drugs (data not shown).

In lipoprotein electrophoresis on cellulose acetate, VLDL, LDL and HDL (protein $=1 \mathrm{~g} / \mathrm{l}$ ) that had been incubated with $100 \mu \mathrm{mol} / \mathrm{l}$ lovastatin showed a substantially reduced electrophoretic mobility (fig. 1). Electrophoretic mobility of ${ }^{14} \mathrm{C}$-labelled drug-treated lipoproteins revealed that the radioactivity was associated with the lipoproteins bands. The drugs did not affect LDL size, or the integrity of apolipoprotein B-

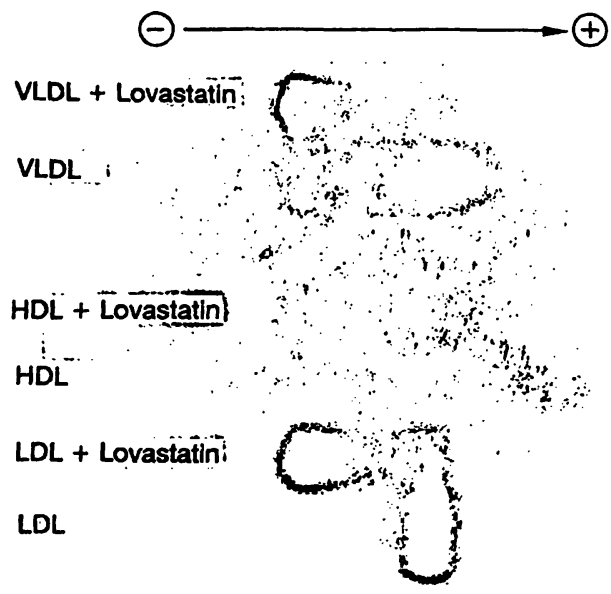

Fig. 1. Electrophoresis of lovastatin-treated lipoproteins on cellulose acetate. Lipoproteins were stained with oil red $O$. VLDL, very low density lipoproteins. LDL, low density lipoproteins. HDL, high density lipoprotein.

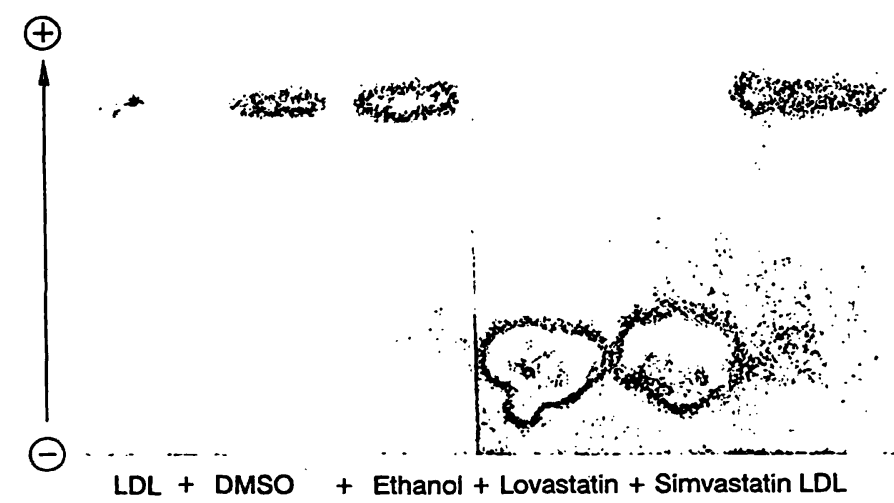

Fig. 2. Electrophoresis of drug-treated LDL on cellulose acetate. DMSO, dimethyl sulphoxide (used for solubilization of lovastatin). Ethanol is used for solubilization of simvastatin.

100 , as analysed by non-denatured gradient gels and by SDS polyacrylamide gel electrophoresis (data not shown). Both lovastatin- and simvastatin-associated LDL, like native LDL, showed minimal oxidation $(0.3-0.7 \mathrm{nmol}$ malondialdehyde equivalents per $\mathrm{mg}$ protein). Simvastatin- and lovastatin-treated LDL displayed reduced electrophoretic mobility (fig. 2) and this could not be attributed to the drug solvents (DMSO or ethanol, fig. 2). Pravastatin however, which is an open acid molecule, did not affect lipoprotein electrophoretic mobility (data not shown). Lovastatin was found to affect lipoprotein fluidity, mainly that of LDL. The fluidity of lovastatin-treated LDL was increased by $28 \%$ in comparison with the fluidity of control LDL (fig. 3). The effect of the drugs on LDL immunoreactivity was tested using monoclonal antibody $\mathrm{B} 1 \mathrm{~B} 6$, which is directed towards 


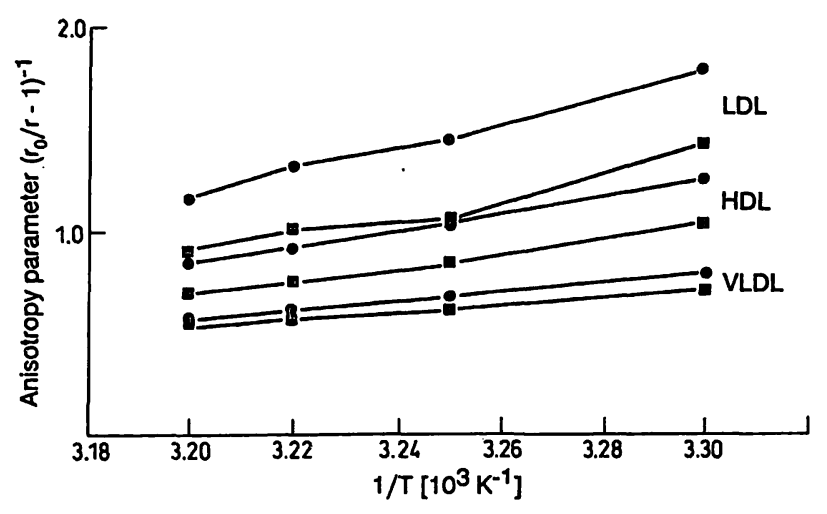

Fig. 3. Fluidity of lovastatin-treated lipoprotein. Lipoproteins $(1 \mathrm{~g}$ of protein per litre) were incubated without $(\bullet)$ or with (a) $100 \mu \mathrm{mol} / 1$ lovastatin for $1 \mathrm{~h}$ at $37^{\circ} \mathrm{C}$. The nuidity of the lipoprotein was then measured as described under Methods. The fluidity is inversely related to the anisotropy parameter (which is expressed under several temperature points). Results are representative of 3 different experiments.

the LDL receptor binding domains on apolipoprotein B-100. Figure 4 demonstrates the reduced immunoreactivity of lovastatin- and simvastatin-associated LDLs in comparison with control LDL treated with either DMSO or ethanol.

$\mathrm{ED}-25$ values (the concentration of unlabelled lipoprotein required to reduce the immunoreactivity to $25 \%$ of control) for lovastatin- and simvastatintreated LDL were 27 and $25 \mathrm{mg} / \mathrm{l}$ compared with 12 and $9 \mathrm{mg} / \mathrm{l}$ for the appropriate controls, respectively (fig. 4). Analysis of drug binding to macrophages revealed that both lovastatin and simvastatin bind to macrophages (tab. 3).
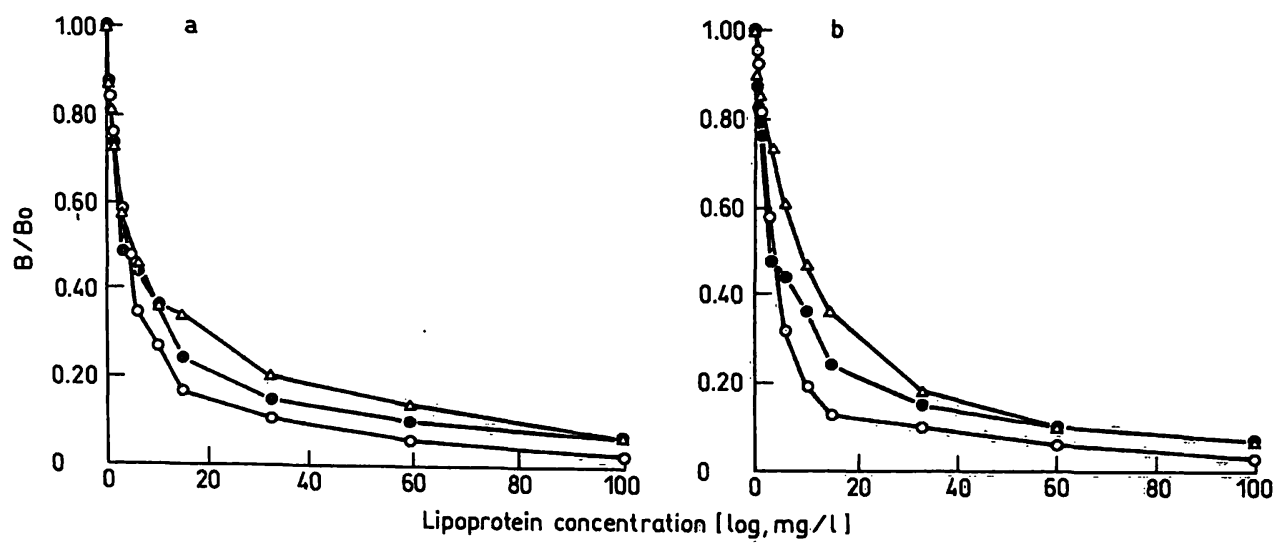

Fig. 4. Immunoreactivity of drug-treated LDL against the monoclonal antibody B1B6. Microtitre wells were coated with the monoclonal antibody B1 B6 (10 mg/l) for 18 hours. The assay was carried out as described under Methods using serial dilutions of LDL, control LDL (with the appropriate solvent) and drug-associated LDL. The results are expressed as the ratio of the individual radioactivity counts $(B)$ to those obtained in the absence of competitor $\left(\mathrm{B}_{\circ}\right)$.

a) Lovastatin

$$
\begin{array}{ll}
\bullet-\bullet & \text { LDL } \\
0-0 & \text { LDL + DMSO } \\
\Delta-\triangle & \text { LDL + lovastatin }
\end{array}
$$

Tab. 3. Macrophage binding of lovastatin or simvastatintreated LDL.

\begin{tabular}{ll}
\hline Drug & $\begin{array}{l}\text { Macrophage-associated drug } \\
\text { ( } \% \text { of added radioactivity) }\end{array}$
\end{tabular}

\begin{tabular}{lc}
\hline A. $100 \mu \mathrm{mol} / 1$ & \\
Lovastatin & $0.2 \pm 0.01$ \\
Lovastatin-LDL & $11 \pm 0.9$ \\
Simvastatin & $0.4 \pm 0.04$ \\
Simvastatin-LDL & $19 \pm 1.3$
\end{tabular}

B. $1 \mu \mathrm{mol} / 1$

Lovastatin

Lovastatin-LDL

$0.8 \pm 0.2$

Simvastatin

$9.5 \pm 0.7$

Simvastatin-LDL

$16.7 \pm 22$

J-774A.1 macrophages were incubated for $1 \mathrm{~h}$ at $37^{\circ} \mathrm{C}$ with ${ }^{14}[$ C $]$ lovastatin, ${ }^{14}[\mathrm{C}]$ simvastatin or LDL (protein $=25 \mathrm{mg} / \mathrm{l}$ ) associated with either ${ }^{14} \mathrm{C}$-labelled lovastatin or with ${ }^{14} \mathrm{C}$-labelled simvastatin. Drug-associated LDLs were prepared by incubation of plasma with the labelled drugs followed by separation. Cells were washed $(x 3)$ with phosphate-buffered saline and cell-associated radioactivity was determined. Drugs were used at two concentrations: A - $100 \mu \mathrm{mol} / \mathrm{l}, \mathrm{B}-1 \mu \mathrm{mol} / \mathrm{l}$. Results are mean \pm S.D. of 3 experiments.

At lower, more physiological concentrations, however, drug binding to the cells increased; simvastatin binding to the cells was about twice that of lovastatin. The binding efficiency of each drug was substantially higher when it was introduced to the cells in association with LDL, rather than as the free compound (tab. 3).

The effect of drug treatment of LDL on its cellular binding, uptake and degradation were studied in $\mathrm{J}$ 774 A.1 macrophage-like čèll line and in human skin 
Tab. 4. Macrophage uptake and degradation of lovastatin- or simvastatin-treated LDL.

\begin{tabular}{lll}
\hline & $\begin{array}{l}\text { Cholesterol } \\
\text { esterification } \\
\text { (nmol/mg cell } \\
\text { protein per 5 h) }\end{array}$ & $\begin{array}{l}\text { Lipoprotein } \\
\text { degradation } \\
\text { (ng/mg cell } \\
\text { protein per 5 h) }\end{array}$ \\
\hline LDL & $0.8 \pm 0.2$ & $1335 \pm 133$ \\
\hline LDL-DMSO & $0.5 \pm 0.3$ & $1411 \pm 128$ \\
$\begin{array}{l}\text { LDL-lovastatin } \\
(100 \mu \text { mol/l) }\end{array}$ & $1.5 \pm 0.4^{*}$ & $2693 \pm 303^{*}$ \\
$\begin{array}{l}\text { LDL-lovastatin } \\
(1 \mu \text { mol/l) }\end{array}$ & $1.2 \pm 0.2^{*}$ & $2099 \pm 195^{*}$ \\
\hline $\begin{array}{l}\text { LDL-Ethanol } \\
\text { LDL-simvastatin } \\
(100 \mu m o l / l)\end{array}$ & $1.8 \pm 0.3^{*}$ & $1993 \pm 211^{*}$ \\
$\begin{array}{l}\text { LDL-simvastatin } \\
(1 \mu \text { mol/l) }\end{array}$ & $1.1 \pm 0.2^{*}$ & $2011 \pm 101^{*}$ \\
\hline
\end{tabular}

J-774A.1 macrophage cell line $\left(10^{6} / 16 \mathrm{~mm}\right.$ well $)$ were incubated with $25 \mathrm{mg}$ of protein per litre of unlabelled liproproteins or with ${ }^{125}$ I-labelled lipoproteins (that were previously treated with drugs or with solvents) for $5 \mathrm{~h}$ at $37^{\circ} \mathrm{C}$. Cellular cholesterol esterification rate and macrophage degradation of the lipoproteins were analysed as described under Methods. The liproproteins were pretreated with the drugs $(100 \mu \mathrm{mol} / \mathrm{l}$ or $1 \mu \mathrm{mol} / \mathrm{l})$ for 1 hour at $37^{\circ} \mathrm{C}$ followed by LDL separation (by ultracentrifugation). Control LDLs were similarly prepared but they were treated with the appropriate solvents instead of drugs. Results are mean $\pm S$. D. of 3 experiments *p $<0.01$ (vs. the appropriate control). DMSO - Dimethylsulphoxide.

fibroblasts. Lovastatin-treated $\left[{ }^{125} \mathrm{I}\right] \mathrm{LDL}$ (protein $=25 \mathrm{mg} / \mathrm{l})$ binds at $4{ }^{\circ} \mathrm{C}$ to macrophages $28 \%$ less than control LDL $(350 \pm 37$ vs. $448 \pm 49 \mathrm{ng} / \mathrm{mg}$ cell protein respectively, $\mathrm{n}=3$ ). Similarly, the binding of lovastatin-treated LDL to human skin fibroblasts was reduced by $27 \%$ (from $839 \pm 39$ to $611 \pm 44 \mathrm{ng} / \mathrm{mg}$ cell protein, $n=3$ ). The cellular uptake of lipoproteins (protein $=25 \mathrm{mg} / \mathrm{l}$ ), as assessed by the macrophage cholesterol esterification rate, however, showed a $83 \%$ and $67 \%$ increased uptake of lovastatin (100 $\mu \mathrm{mol} / \mathrm{l})$-treated LDL and simvastatin-treated $\mathrm{LDL}$ respectively, in comparison with the control LDLs (tab. 4). Similarly, the macrophage degradation of these drug-associated LDLs increased by $89 \%$ and $87 \%$, respectively (tab. 4). Similar effects were observed when a drug concentration of only $1 \mu \mathrm{mol} / 1$ was used (tab. 4). In human skin fibriblasts, the cellular degradation of control LDL and lovastatintreated LDL ( $100 \mu \mathrm{mol} / 1$ and $1 \mu \mathrm{mol} / 1$ of lovastatin) were $1991 \pm 101,3893 \pm 233$ and $2713 \pm 188 \mathrm{ng} /$ $\mathrm{mg}$ cell protein respectively $(\mathrm{n}=3)$. Figure 5 shows lipoprotein dose response curves for the macrophage degradation of lovastatin-associated LDL and of native LDL. At all lipoprotein concentrations studied,

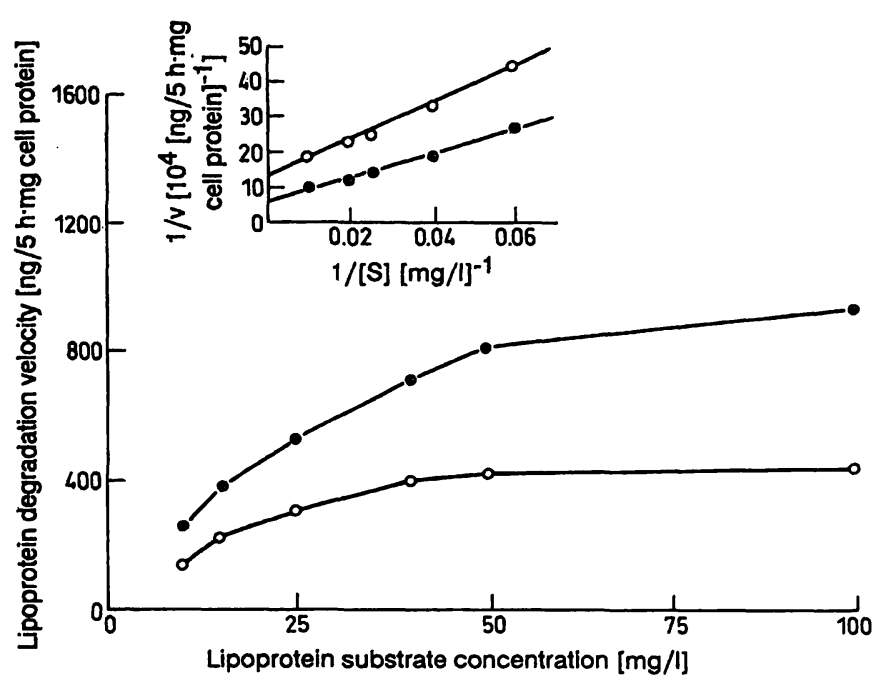

Fig. 5. A dose response curve of macrophage degradation of lovastatin-associated LDL (0) and native LDL (0). ${ }^{125} \mathrm{I}-\mathrm{LDL}(1 \mathrm{~g}$ of protein per litre) was incubated with $100 \mu \mathrm{mol} / 1$ lovastatin for $2 \mathrm{~h}$ at $37^{\circ} \mathrm{C}$ and separated by ultracentrifugation prior to its addition $(25 \mathrm{mg}$ of protein per litre) to J-774A.1 macrophages. Cellular degradation of increasing concentrations of the lipoproteins was determined as described under Methods. Results are the means of triplicates; they are representative of the results of two experiments which varied by less than $10 \%$. The lipoprotein substrate concentration [S] refers to protein, $\mathrm{mg} / \mathrm{l}$.

the cellular degradation of lovastatin-associated-LDL was substantially higher than that of the untreated lipoproteins (fig. 5). Analysis of the data by the $\mathrm{Li}$ neweaver-Burk plot revealed that the "apparent $\mathrm{V}_{\max }$ " for lovastatin-associated LDL was 1.7 times higher than that for native LDL, with no significant effect on "apparent $K_{\mathrm{m}}$ " (fig. 5, insert). Macrophage degradation of lovastatin-associated $\left[{ }^{125}\right] \mathrm{LDL}$ (LDLLOV, protein $=10 \mathrm{mg} / \mathrm{l}$ ) was substantially reduced by $500 \mathrm{mg} / \mathrm{l}$ of unlabelled lovastatin-associated LDL (from $345 \pm 35$ to $75 \pm 17 \mathrm{ng} / \mathrm{mg}$ cell protein per $5 \mathrm{~h}$ ). When native unlabelled LDL or acetyl LDL were used at similar concentrations, the cellular degradation of lovastatin-associated [ $\left.{ }^{125} \mathrm{I}\right] \mathrm{LDL}$ was 89 \pm 24 and $337 \pm 29 \mathrm{ng} / \mathrm{mg}$ cell protein, respectively, suggesting that lovastatin-associated LDL binds to the macrophage LDL receptor and not to the scavenger receptor.

\section{Discussion}

The present study demonstrates the binding of lovastatin and simvastatin to plasma lipoproteins over a wide range of concentrations including those found in plasma during clinical dosage. Such drug binding was shown to affect lipoprotein physico-chemical characteristics, including reduced lipoprotein electro- 
phoretic mobility, increased fluidity and reduced immunoreactivity with the monoclonal antibody B1 B6, which is directed against the LDL receptor binding domains on apolipoprotein B-100. Uptake of drugassociated LDL by macrophages and fibroblasts was higher than that of native LDL. Even though the drugs may reduce the affinity of LDL for the LDL receptor, the net effect of the drug was to increase cellular uptake of the lipoprotein. This effect resulted from the increased number of LDL receptors on the cell surface which more than compensated for the reduced binding affinity of drug-treated LDL for the LDL receptor.

It is of interest that simvastatin showed increased binding to lipoproteins and macrophages in comparison with lovastatin. This may be related to the additional methyl group on the simvastatin molecule (18). Lovastatin and simvastatin, which are administered as the lactone forms, are present in the systemic circulation. both as open chain acids $(62 \%)$ and as closed-ring lactones (38\%), both of which are potentially active (7). In the present study we used the lactone forms of the drugs. Although the active form of lovastatin is the acid, there are also many other active metabolites (19). The presence of non-metabolized lovastatin in the circulation (as the lactone) can affect cellular metabolism of LDL via mechanism other than inhibition of cellular cholesterol synthesis. Cellular uptake of the drugs may also result in the hydrolysis of the lactone to the acid form, thus causing cellular cholesterol biosynthesis inhibition with subsequent increased synthesis of receptors for LDL. Recently it was shown that both lovastatin and simvastatin, when used in the lactone form, inhibited cholesterol biosynthesis in human monocyte-derived macrophages (20).

The molecular size of the drug-treated lipoproteins was unchanged according to gradient gel electrophoresis analysis under non-denaturing conditions. Both drugs, however, reduced the electrophoretic mobility of LDL; this may be due to a changed conformation of the lipoprotein surface and the altered availability of charged surface phospholipids. It is well documented that the charge of LDL affects its uptake by macrophages $(21-23)$.

Increased uptake of LDL by macrophages has been demonstrated following lipoprotein oxidation (22, 23). In our study, however, the drug did not affect the oxidation state of LDL. Furthermore, LDL apolipoprotein B-100 fragmentation, which is associated with lipoprotein oxidation $(22-24)$, did not take place in drug-associated LDL.
LDL fluidity was recently shown to be significantly reduced following incubation with platelet secretory products (25). Lipoprotein fluidity depends on its cholesterol to phospholipid ratio and on its fatty acid composition (26). Since the cholesterol and phospholipid contents were not changed in drug-associated LDL, it is possible that drug binding to the lipoprotein is associated with its interaction with phospholipid fatty acids. The increased lipoprotein fluidity observed in lovastatin-associated LDL may contribute to the enhanced cellular uptake of drug-associated LDL. Increased LDL fluidity following lovastatin therapy in hypercholesterolaemic patients was recently demonstrated in our laboratory (Aviram, $M$. et al., unpublsihed observation).

Both drugs reduced the immunoreactivity of LDL towards monoclonal antibody $\mathrm{B} 1 \mathrm{~B} 6$, which recognizes epitopes at the LDL receptor binding domains of apolipoprotein B-100. This reduced immunoreactivity of the modified LDL may be related to the changes in lipoprotein charge, as suggested from the reduction in its electrophoretic mobility. Whereas the free drugs bind poorly to macrophages and fibroblasts, they bind substantially to these cells when associated with LDL. This phenomenon is the result of the high binding affinity of the lipoprotein for cells (27). It is possible that in vivo LDL is responsible for delivering the drugs into the cells. The hypocholesterolaemic effect of the drugs is related to their ability to inhibit the rate-limiting enzyme of cholesterol biosynthesis, hydroxymethylglutaryl-coenzyme A reductase (HMG-CoA reductase) $(1,2)$. This effect in turn results in increased synthesis of of LDL receptors (28), and thus more LDL can be taken up by the cells and plasma cholesterol is reduced. The present study showed that the "apparent $\mathrm{V}_{\max }$ " for lovastatin-associated LDL was higher than that for control LDL, suggesting that the drug increased the number of $L \bar{D} \dot{L}$ receptors on the cell surface (probably following its intracellular conversion to the active acid form). From the reduced immunoreactivity of drug-associated LDL with the monoclonal antibody B1B6 and from its reduced cellular binding affinity, it can be expected that its uptake by the macrophage LDL receptor will be also reduced. In our study however, drug-associated LDLs were taken up and degraded by macrophages and by fibroblasts at increased rate in comparison with native LDL. Drug binding to LDL may cause conformational changes in apolipoprotein B100 (as suggested from the reduced immunoreactivity of drug-associated LDL with the monoclonal antibody B1B6) and this in turn could reduce the affinity of the lipoprotein for the cellular LDL receptor. On 
the other hand, the ability of LDL to effectively deliver drug into the cells via the LDL receptor pathway, contributes to a specific inhibition of HMGCoA reductase with a subsequent reduction in cellular cholesterol biosynthesis and an induction of LDL receptor synthesis. This latter effect of lovastatin, which results in an increased number of LDL receptors on the cell surface, is the major effect of the drug on the cellular uptake of LDL, since the net effect of lovastatin-associated LDL was to increase the cellular uptake and degradation of the lipoprotein. Thus, the reduced affinity of lovastatin-associated LDL for the
LDL receptor might contribute far less to the cellular uptake of the lipoprotein than the increased number of LDL receptors. In certain pathological conditions, the magnitude of the opposing effects of lovastatin on LDL uptake by macrophages would determine the amount of cellular cholesterol accumulation.

\section{Acknowledgement}

The authors thank Mrs. Gertrude Dankner, Edna Hochgraf and Mira Rosenblat for excellent technical assistance and Mrs. Ilana Choen for typing this manuscript.

\section{References}

1. Alberts, A. W., Chen, J., Kuron, G., Hunt, V. \& Huff, J. (1980) Mevinolin: a highly potent competitive inhibitor of hydroxymethyl-glutaryl coenzyme $A$ reductase and cholesterol. Proc. Natl. Acad. Sci. U. S. A. 77, 3957-3961.

2. Grundy, S. M. \& Bilheimer, D. W. (1984) Inhibition of 3hydroxy-3-methylglutaryl CoA reductase by mevinolin in familial hypercholesterolemic heterozygotes: Effect on cholesterol balance. Proc. Natl. Acad. Sci. U.S. A. 81, 25392542.

3. Pappu, A. A., lllingworth, D. R. \& Bacon, S. (1989) Reduction in plasma low density lipoprotein cholesterol and urinary mevalonic acid by lovastatin in patients with heterozygous familial hypercholesterolemia. Metabolism 38, $542-548$.

4. Berglund, L., Sharkey, M. F., Elan, R. L. \& Witztum, J. L. (1989) Effect of lovastatin therapy on guinea pig low density lipoprotein composition and metabolism. J. Lipid Res. 30, $1591-1599$.

5. Reynold, G. A. (1989) Rational therapy of familial hypercholesterolemia. Circulation 79, 1146-1148.

6. Aviram, M. (1983) Plasma lipoprotein separation by discontinuous density gradient ultracentrifugation in hyperlipoproteinemic patients. Biochem. Med. 30, 111-118.

7. Pan, H. Y., Devault, A. R., Wang-Iverson, D., Ivashkiv, E., Swanson, B. N. \& Sugerman, A. (1990) Comparative pharmacokinetics and pharmacodynamics of pravastatin and lovastatin. J. Clin. Pharmacol. 30, 1128-1135.

8. Hagemenas, F. C. \& Illingwoith, D. R. (1989) Cholesterol homeostasis in mononuclear leukocytes from patients with familial hypercholesterolemia treated with lovastatin. Arteriosclerosis $9,355-361$.

9. Colf, B. \& Verheyden, J. (1967) Electrophoresis and sudan black staining of lipoproteins on gelatinised cellulose acetate. Clin. Chim. Acta. 18, 325-329.

10. Swaney, J. B. \& Knen, D. S. (1976) Separation of apolipoproteins by an acrylamide-gradient sodium dodecyl sulfate gel electrophoresis system. Biochim. Biophys. Acta 446, $561-565$.

11. Krauss, R. M. \& Burke, D. J. (1982) Identification of multiple subclasses of plasma low density lipoprotein in normal humans. J. Lipid. Res. 23, 99-104.

12. Lowry, O. H., Rosebrough, N. J., Farr, J. L. \& Randall, R. J. (1951) Protein measurement with the Folin phenol reagent. J. Biol. Chem. 193, 265-275.

13. Bartlett, G. R. (1959) Phosphorus assay in column chromatography. J. Biol. Chem. 234, 466-472.

14. Buege, J. A. \& Aust, S. D. (1978) Microsomal lipid peroxidation. Methods Enzymol. 52, 302-310.
15. Keidar, S., Goldberg, A. C., Cook, K., Bateman, J. \& Schonfeld, G. (1990) A high carbohydrate-fat free diet alters the proportion of heparin-bound VLDL in plasma and the expression of VLDL-apoB-100 epitopes. Metabolism 29, 937-947.

16. Berlin, E. \& Young, C. (1983) Effects of fat level, feeding period and source of fat on lipid fluidity and physical state of rabbit plasma lipoproteins. Atherosclerosis 48, 15-22.

17. Aviram, M., Fuhrman, B., Keidar, S., Maor, I., Rosenblat, M., Dankner, G. \& Brook, J. G. (1989) Platelet-modified low density lipoprotein induces macrophage cholesterol accumulation and platelet activation. J. Clin. Chem. Clin. Biochem. 27, 3-12.

18. Mosley, S. T., Kalinowski, S. S., Schafer, B. L. \& Tanaka, R. D. (1989) Tissue-selective acute effects of inhibitors of 3-hydroxy-3-methylglutaryl coenzyme A reductase on cholesterol synthesis in lens. J. Lipid. Res. 30, 1411-1420.

19. Stubbs, R. J., Schwartz, M. \& Bayne, W. F. (1986) Determination of mevinolin and mevinolinic acid in plasma and bile by reverse-phase high performance liquid chromatography. J. Chromatog. 383, 438-443.

20. Kempen, H. J. M., Vermeer, M., deWitt, E. \& Havekes, L. M. (1991) Vastatins inhibit cholesterol ester accumulation in human monocyte-derived macrophages. Arteriosclerosis $11,146-153$.

21. Goldstein, J. L., Ho, Y. K., Basu, S. K. \& Brown, M. S. (1979) Binding site on macrophages that mediates uptake and degradation of acetylated low density lipoproteins producing massive cholesterol deposition. Proc. Natl. Acad. Sci. U.S. A. 76, 333-337.

22. Steinberg D, Parthasarathy, S., Carew, T. E., Khoo, J. C. \& Witztum, J. L. (1989) Modification of low density lipoprotein that increases its atherogenicity. New Eng. J. Med. 320, 915-924.

23. Aviram, M. (1991) The effect of lipoproteins and platelets on macrophage cholesterol metabolism. In: Blood Cell Biochemistry, Vol. 2: Megakaryocytes, Platelets, Macrophages and Eosinophils (Harris, J. R., ed.). Plenum Press Publishing, NY. Chapter 7, pp. 179-208.

24. Steinbrecher, U. P. (1987) Oxidation of human low density lipoprotein results in derivatization of lysine residues of apolipoprotein B by lipid peroxide decomposition products. J. Biol. Chem. 262, 3603-3608.

25. Aviram, M., Dankner, G. \& Brook, J. G. (1990) Platelet secretory products increase LDL oxidation, enhance its uptake by macrophages and reduce its fluidity. Arteriosclerosis $10,559-563$. 
26. Hale, J. E. \& Schroeder, F. (1981) Differential scanning calorimetry and fluorescence probe investigation of very low density lipoprotein from the isolated perfused rat liver. J. Lipid. Res. 22, 838-842.

27. Goldstein, J. L., Dana, S. E. \& Brown, M. S. (1974) Binding and degradation of low density lipoproteins by cultured human fibroblasts. J. Biol. Chem. 249, 5153-5162.
28. Raveh, D., Israeli, A., Arnon, R. \& Eisenberg, S. (1990) Effect of lovastatin therapy on LDL receptor activity in circulating monocytes and on structure and composition of plasma lipoproteins. Atherosclerosis 82, 19-26.

Prof. Dr. Michael Aviram

Lipid Research Laboratory

Rambam Medical Center

Haifa

Israel 